\title{
SISTEM PENUNJANG KEPUTUSAN PEMILIHAN TRAINER WORKSHOP PADA LABORATORIUM ICT TERPADU UNIVERSITAS BUDI LUHUR MENGGUNAKAN METODE ANALYTICAL HIERARCHY PROCESS (AHP) DAN PROFILE MATCHING
}

\author{
Humisar Hasugian $^{1)}$, Septiya Hiryani ${ }^{2)}$ \\ Sistem Informasi, Fakultas Teknologi Informasi, Universitas Budi Luhur \\ Jl. Raya Ciledug, Petukangan Utara, Kebayoran Lama, Jakarta Selatan 12260 \\ E-mail :humisar.hasugian@ budiluhur.ac.id ${ }^{1)}$ septiyahiryani8@ gmail.com ${ }^{2)}$
}

\begin{abstract}
Abstrak
Laboratorium ICT Terpadu adalah salah satu organisasi yang bergerak dalam bidang pelayanan kepada mahasiswa dan dosen yang berada dalam lingkungan Universitas Budi Luhur. Salah satu kegiatan atau program kerja yang ada adalah program workshop. Dalam pelaksanaan workshop ini tentunya tidak terlepas dari peran trainer yang memandu berjalannya workshop tersebut. Pada dasarnya keberhasilan suatu workshop dipengaruhi oleh beberapa faktor salah satunya kompetensi trainer. Dalam proses mengambil keputusan pemilihan trainer Kepala Lab ICT masih menggunakan cara manual dengan menunjuk secara langsung kandidat yang pantas sebagai trainer dimana kemungkinan menimbulkan permasalahan kandidat yang dipilih tidak sesuai dengan bidang yang akan diajarkan, yang berdampak peserta workshop merasa tidak puas. Untuk mengatasi permasalahan tersebut maka dirancanglah sistem penunjang keputusan secara terkomputerisasi dengan menggunakan metode Analytical Hierarchy Process (AHP) yang digunakan untuk membantu pengambil keputusan dalam menentukan besar pembobotan tiap kriteria dan metode Profile Matching untuk menentukan perangkingan prioritas masing-masing kandidat sesuai dengan target yang diinginkan, adapun sistem yang dirancang menggunakan pemrograman PHP dan database Mysql. Sehingga dihasilkan sebuah sistem informasi berbasis web yang akan membantu kepala lab ICT dalam memilih trainer workshop di Lab ICT.
\end{abstract}

Kata kunci: Trainer Workshop, Profile Matching, Sistem Penunjang Keputusan, Analytical Hierarchy Process

\section{Pendahuluan}

Laboratorium ICT Terpadu Universitas Budi Luhur merupakan organisasi yang berada di lingkungan Universitas Budi Luhur yang bergerak dalam bidang pelayanan kepada mahasiswa maupun dosen. Dalam satu tahun ajaran, workshop adalah salah satu kegiatan atau program kerja yang pasti terlaksana. [1]

Dalam pelaksanaan workshop tersebut tentunya tidak terlepas dari peran mentor atau trainer. Pada prakteknya, keberhasilan suatu pelatihan atau workshop dipengaruhi oleh beberapa faktor, salah satunya yaitu kompetensi trainer itu sendiri. Proses penentuan trainer ternyata tidak sesederhana yang dibayangkan karena harus sesuai dengan kriteria yang telah ditentukan demi terciptanya trainer-trainer yang berkualitas.

Dalam mengambil keputusan pemilihan trainer workshop yang dilakukan di Laboratorium ICT Terpadu terdapat beberapa masalah antara lain (1) Pemilihan trainer workshop masih bersifat subjektif, sehingga sering kali trainer yang ditunjuk mengelak karena merasa tidak menguasai materi. (2) Pengambilan keputusan tidak sesuai dengan yang diharapkan karena belum terdapat pembobotan untuk setiap kriteria. (3) Kepala Laboratorium merasa kesulitan dalam melakukan proses pengolahan data dan rekap hasil penilaian sehingga mengakibatkan proses pemilihan trainer workshop menjadi lama dan kurang maksimal. (4) Trainer mempelajari materi yang tidak dikuasai sehingga effort yang dilakukan berkali-kali lipat.

Berdasarkan kendala yang dihadapi tersebut diperlukan suatu sistem yang dapat memberikan bantuan dalam proses pengambilan keputusan. Oleh karena itu penelitian ini membuat suatu sistem penunjang keputusan yang akan membantu dalam pengambilan keputusan pemilihan trainer workshop yang berkualitas pada Laboratorium ICT Terpadu Universitas Budi Luhur.

Dalam penelitian ini menggunakan metode AHP (Analytical Hierarchy Process) dan Profile Matching. Adapun Metode Analytical Hierarchy Process digunakan untuk menentukan besar pembobotan tiap kriteria, karena Kepala Lab ICT Terpadu Universitas Budi Luhur belum mendefinisikan bobot untuk menentukan calon trainer yang diterima dari setiap kriteria yang ada dan metode Profile Matching digunakan untuk menentukan perankingan prioritas yang memudahkan user untuk melihat calon trainer yang paling sesuai dengan kriteria sehingga diharapkan dapat mempermudah pengambil keputusan dalam menentukan calon trainer yang cocok.

Penelitian sebelumnya yang berjudul Sistem Pendukung Keputusan Pemilihan Trainer Menggunakan Metode ARAS (Additive Ratio Assesment) oleh Dewi Shinta Wulandari dan Eka Murlisah dengan instansi STIM SUKMA MEDAN dan STMIK Budi Dharma Medan tahun 2019 dengan nomor ISBN 978-602-52720-1-1. Tujuan 
dari penelitian ini yaitu untuk membangun sebuah sistem pendukung keputusan yang akan membantu menentukan siapa yang berhak untuk direkrut menjadi seorang pengajar / trainer yang akan mengajar para siswa. Metode yang digunakan pada penelitian ini yaitu ARAS (Additive Ratio Assesment). Kriteria yang digunakan dalam penelitian ini yaitu pendidikan terakhir, nilai indeks prestasi kumulatif (IPK), usia, status mengajar dan ujian tertulis. Hasil dari penelitian yang telah dilakukan yaitu proses pembobotan kriteria pada metode ARAS akan sangat berpengaruh pada hasil akhir perankingan dalam sistem pendukung keputusan pemilihan trainer. Dengan nilai bobot uang berbeda, hasil yang didapat juga akan berbeda. Dengan kata lain nilai bobot menjadi penentu hasil akhir yang ingin diperoleh pengambil keputusan. [2]

Penelitian sebelumnya yang yang berjudul Implementasi Metode AHP dan SAW Pada Aplikasi Sistem Penunjang Keputusan Supplier Terbaik Studi Kasus: CV. Sentra Jamu Indonesia, dalam Jurnal IDEALIS Volume 2 No. 4. Tujuan utama dari penelitian ini yaitu membuat sistem penunjang keputusan untuk meningkatkan kualitas dan mutu pelayanan agar dapat tercapai dengan baik sesuai dengan kriteria yang telah ditetapkan oleh CV. Sentra Jamu Indonesia. Metode yang digunakan dalam penelitian ini adalah Analytical Hierarchy Process (AHP) dan Simple Additive Weighting (SAW). Kriteria yang digunakan dalam penelitian ini yaitu kualitas, harga, pelayanan dan waktu pengiriman. Hasil dari penelitian yang telah dilakukan yaitu sistem yang dibuat dapat membantu dalam penentuan supplier terbaik karena proses penyajian laporan menjadi lebih cepat dan akurat sehingga dapat mengurangi keterlambatan dalam pengiriman bahan baku serta meningkatkan kualitas bahan baku. [3]

\section{METODOLOGI PENELITIAN}

\subsection{Kerangka Pemikiran}

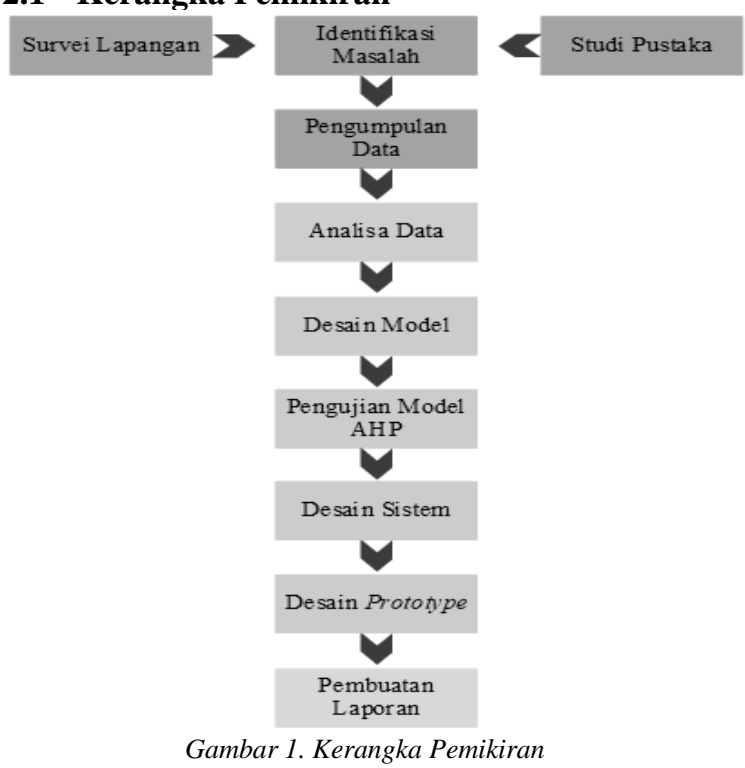

Pada Gambar 1 merupakan kerangka pemikiran yang digunakan berawal dari perumusan masalah untuk proses pemilihan trainer workshop pada Laboratorium ICT Terpadu Universitas Budi Luhur dengan melakukan proses identifikasi masalah dengan cara survei lapangan dan studi pustaka. Survei lapangan dengan cara mendatangi Kepala Laboratorium ICT Terpadu Universitas Budi Luhur, kemudian studi pustaka yang dilakukan yaitu dengan mencari studi kasus pengambilan keputusan yang mempuyai masalah yang sama tetapi dengan berbagai metodologi. Proses pencarian berasal dari jurnal-jurnal. Langkah selanjutnya pengumpulan data yang didapat dari Kepala Laboratorium. Setelah tahap pengumpulan data, maka dilakukan Analisa terhadap data tersebut, lalu dilanjutkan dengan tahap desain model, pengujian pertama pada penelitian ini yaitu dengan model Analytical Hierarchy Process (AHP) [4] dengan cara membandingkan nilai per kriteria untuk mendapatkan nilai bobot per kriteria, kedua yaitu model Profile Matching [5] dengan cara membandingkan nilai dari profil asisten dengan nilai dari profil target. Kemudian desain system berdasarkan desain model yang telah dibuat. Kemudian desain prototype untuk menentukan asisten yang terpilih sebagai trainer workshop. Pada tahap terakhir dilakukan pembuatan laporan dari hasil penelitian yang dilakukan.

\subsection{Metode Pengumpulan Data}

Adapun metode yang digunakan untuk mengumpulkan data, informasi, dan materi yang sesuai dengan permasalahan pada Lab ICT Terpadu Universitas Budi Luhur, yaitu:

1) Observasi

Observasi ini dikukan di Laboratorium ICT Terpadu, Unit 7 Lantai 4, Universitas Budi Luhur. Kegiatan ini dilakukan untuk mengumpulkan data sebanyak mungkin yang didapatkan melalui pengamatan secara langsung hal-hal yang berkaitan dengan proses penentuan trainer workshop pada Laboratorium ICT Terpadu sebagai masukan penelitian ini. Dalam penelitian ini, yang menjadi target sebagai trainer workshop merupakan asisten Laboratorium ICT Terpadu Universitas Budi Luhur. 2) Wawancara

Kegiatan wawancara dilakukan untuk pengumpulan data secara langsung dengan mengajukan pertanyaan yang berhubungan dengan penentuan trainer workshop yang dilakukan oleh Ibu Painem, M.Kom selaku Kepala Laboratorium. Kepala Laboratorium sebagai pihak yang berwenang untuk melakukan pemilihan trainer workshop. Dari wawancara tersebut, penulis juga mengumpulkan dokumen yang berkaitan dengan pengembangan sistem penunjang keputusan penentuan trainer workshop.

3) Analisa Dokumen

Analisa dokumen berfungsi untuk mencari data dan informasi berdasarkan dokumen-dokumen 
berjalan yang digunakan pada Lab ICT Terpadu serta menganalisa dokumen agar didapatkan informasi yang sesuai dengan sistem yang akan dikembangkan. Dokumen yang digunakan dalam penelitian ini yaitu terkait data asisten, data absensi kehadiran asisten, data kehadiran asistensi asisten, dan form penilaian tes khusus.

4) Studi Pustaka

Penulis memperlajari penelitian-penelitian sebelumnya yang berhubungan dengan metode Analytical Hierarchy Process dan Profile Matching dari berbagai sumber-sumber yang ada seperti $e$ book, jurnal, dan situs-situs internet.

\subsection{Instrumentasi}

Metode penelitian yang digunakan oleh penulis dalam penelitian yaitu dengan cara:

1) Kuesioner, dalam instrumen penelitian ini dilakukan dengan cara penulis memberikan pertanyaan kepada responden yang dibutuhkan dalam laporan penelitian.

2) Wawancara, instrumen ini dilakukan oleh Kepala Laboratorium ICT Terpadu Universitas Budi Luhur untuk memperoleh informasi tentang bagaimana proses pemilihan trainer workshop yang dilakukan oleh Laboratorium ICT Terpadu Universitas Budi Luhur.

\subsection{Teknik Analisa Data}

Analisa deskriptif, metode Analytical Hierarchy Process dan Metode Profile Matching merupakan teknik analisa data yang digunakan pada penelitian ini, Analisa deskriptif dilakukan dengan menyajikan rangkuman yang didapatkan dari hasil pengumpulan data. Sedangkan Analytical Hierarchy Process digunakan untuk menentukan besar pembobotan kriteria, karena Kepala Laboratorium ICT Terpadu Universitas Budi Luhur belum mendefinisikan bobot untuk menentukan asisten yang tepat dari setiap kriteria yang ada dan Metode Profile Matching digunakan untuk menentukan perankingan. Kedua metode tersebut digunakan sebagai instrumen untuk menentukan asisten yang diprioritaskan untuk menjadi trainer workshop di Laboratorium ICT Terpadu Universitas Budi Luhur.

\subsection{Komponen Sistem Penunjang Keputusan}

Decision Support System terdiri dari beberapa subsistem, yaitu Data Management Subsystem, Model Management Subsystem, dan User Interface Subsystem. Beberapa subsystem tersebut dapat dilihat pada Gambar 2.[6]

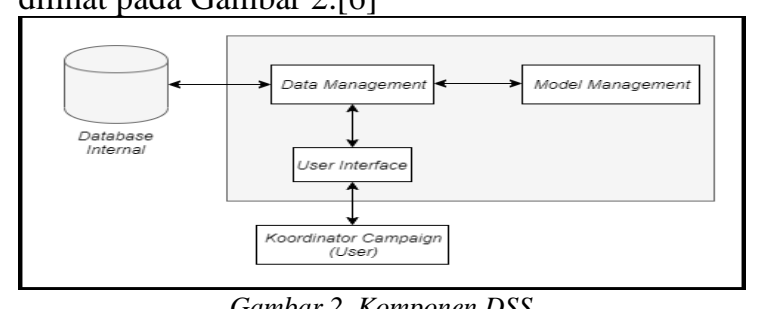

a. Subsistem Manajemen Data (Data Management Subsystem)

Data Management Subsystem menyediakan data, baik dari data internal maupun eksternal. Data internal dalam sistem ini adalah data asisten, kriteria, yang diperoleh dari Kepala Laboratorium ICT Terpadu Universitas Budi Luhur. Data-data internal digunakan untuk melakukan kegiatan pembentukan (create) dan pengaksesan. Data eksternal pada sistem ini adalah data penilaian asisten berupa data kehadiran, kemampuan menyampaikan materi, penguasaan materi sesuai bidang. Data eksternal ini menggambarkan faktor-faktor yang dapat mempengaruhi proses pemilihan trainer workshop.

b. Subsistem Manajemen Model (Model Management Subsystem)

Dalam membuat Sistem Penunjang Keputusan ini digunakan bahasa pemrograman berbasis web dengan framework PHP menggunakan tool Notepad++, dan database MySQL dengan tool MySQL-Front.

c. Subsistem Antar Muka Pengguna (User Interface Subsystem)

Pengguna (user) dapat berkomunikasi dan memerintah Sistem Penunjang Keputusan (Decision Support System) melalui subsistem ini. Pengguna (user) dianggap sebagai bagian dari sistem ini. Subsistem Antarmuka Pengguna (User Interface Subsystem) ini yang interaksi antara sistem dan pembuat pengguna (user). Antarmuka pengguna yang diberikan pada sistem ini adalah input data bidang workshop, nilai target, kriteria, perbandingan kriteria, perhitungan profile matching, dan penentuan hasil keputusan yang dihasilkan dari kriteria sampai laporan asisten yang layak menjadi trainer workshop.

\subsection{Proses Pengembangan Tahap Desain}

Tahap desain dilakukan untuk mempermudah penulis dalam merancang sistem pendukung keputusan yang akan dibangun. Tahap desain meliputi

a. Desain Model Data

Pada penulisan penelitian ini, model data yang digunakan untuk merancang sistem yaitu use case diagram, ERD, LRS dan Class Diagram dengan menggunakan tool draw.io. Draw.io adalah sebuah software yang diakses secara online untuk membuat berbagai macam UML. [1]

b. Desain Rancangan Layar

Pada penulisan penelitian ini penulis menggunakan software Balsamiq Mockup untuk membuat rancangan layar pada sistem yang diusulkan.

\subsection{Proses Implementasi}

Proses ini merupakan tahap penerapan sistem yang sudah didesain atau dirancang, agar sistem yang telah dibuat dapat dioperasikan dan digunakan secara optimal sesuai dengan kebutuhan. Pada 
penulisan penelitian ini, aplikasi ini akan diletakkan pada server sistem Laboratorium ICT Terpadu Universitas Budi Luhur.

\section{HASIL DAN PEMBAHASAN}

\subsection{Analisa Masalah (Fishbone Diagram)}

Dalam menganalisa masalah pada pengambilan keputusan proses pemilihan trainer workshop pada Laboratorium ICT Terpadu Universitas Budi Luhur bisa dilihat pada Gambar 3. Dimana penulis menggunakan Fishbone Diagram dalam menganalisa masalah. [7]

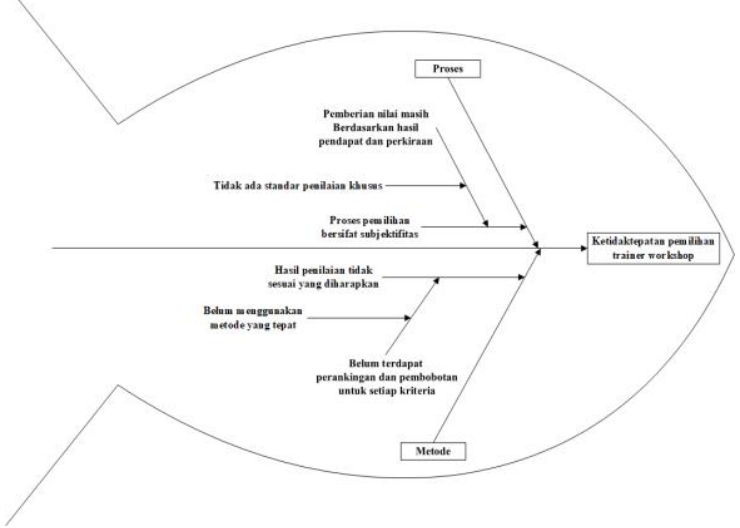

Gambar 3. Fishbone Diagram

\subsection{Proses Bisnis}

Proses pemilihan trainer workshop pada Laboratorium ICT Terpadu Universitas Budi Luhur dilakukan setidaknya satu kali dalam satu tahun ajaran. Proses pemilihan trainer workshop dimulai dari Kepala Laboratorium membuat daftar materi workshop apa saja yang akan diadakan, lalu menginformasikan kepada tim supervisor. Tim supervisor menerima informasi daftar materi workshop apa saja yang akan diadakan dan meneruskan informasi tersebut kepada asisten. Setelah itu asisten menginformasikan materi workshop yang diminati kepada tim supervisor. Kemudian asisten mengikuti Tes Khusus yang diadakan oleh tim supervisor. Pada tes ini, asisten akan dinilai langsung oleh Kepala Laboratorium. Apabila asisten dinyatakan lolos saat tes khusus oleh Kepala Laboratorium, maka tim supervisor akan membuat dan menyerahkan rekap daftar absensi asisten dan daftar hadir asistensi asisten kepada Kepala Laboratorium. Setelah itu Kepala Laboratorium menerima rekap daftar absensi asisten dan daftar hadir asistensi asisten, kemudian melakukan penilaian dengan melihat rekap daftar absensi kehadiran dan daftar hadir asistensi sebagai bahan pertimbangan lainnya. Apabila asisten dinyatakan lolos pada proses penilaian ini, Kepala Laboratorium akan menyerahkan nama asisten tersebut kepada tim supervisor untuk mengkonfirmasi kepada asisten yang bersangkutan bahwa asisten tersebut terpilih sebagai trainer workshop, yang terlihat pada Gambar 4.

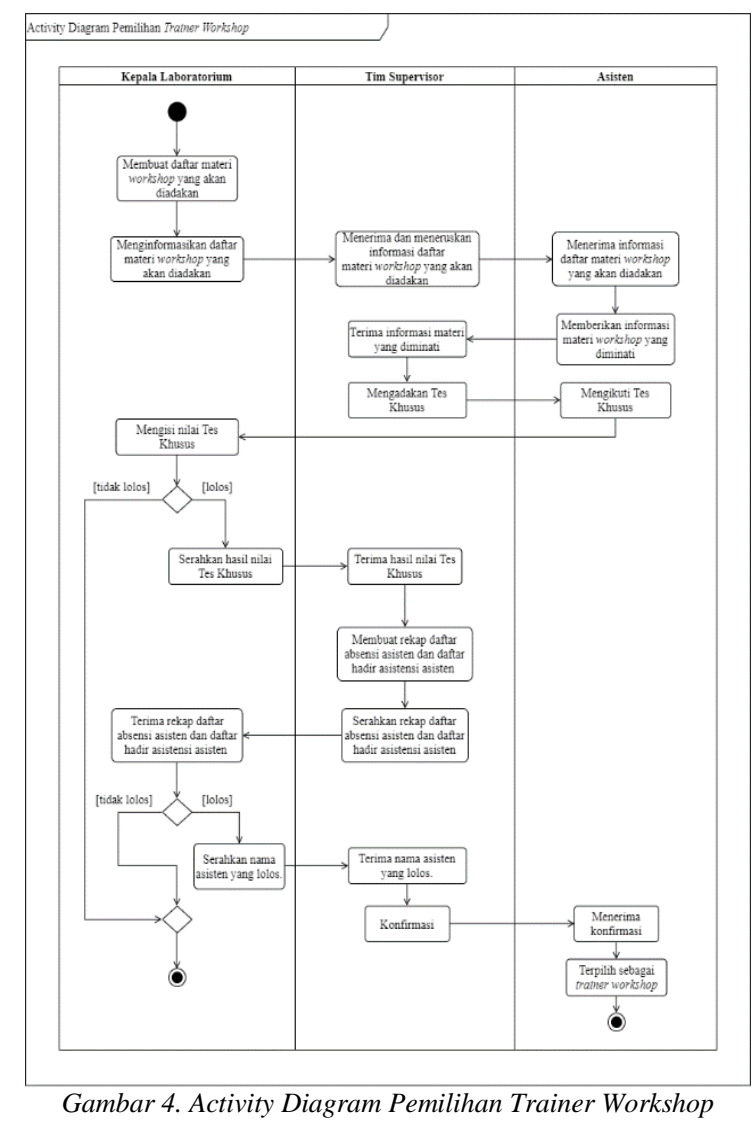

3.4 Model Analytical Hierarchy Process (AHP)

AHP digunakan untuk menurunkan skala rasio dari beberapa perbandingan berpasangan (pairwise comparison) yang bersifat diskrit maupun kontinu. Perbandingan berpasangan dipergunakan untuk membentuk hubungan di dalam struktur [4]. Hasil dari perbandingan berpasangan ini akan membentuk matriks, dimana skala rasio diturunkan dalam bentuk eigenvector utama atau fungsi eigen. Matriks tersebut berdiri positif dan berbalikan, yaitu $\mathrm{a}_{\mathrm{ij}}=$ $1 / a_{i j}$.

Struktur hirarki permasalahan untuk pemilihan trainer workshop pada Laboratorium ICT Terpadu Universitas Budi Luhur dengan beberapa kriteria, subkriteria dan alternatif dapat dilihat pada Gambar 5 .

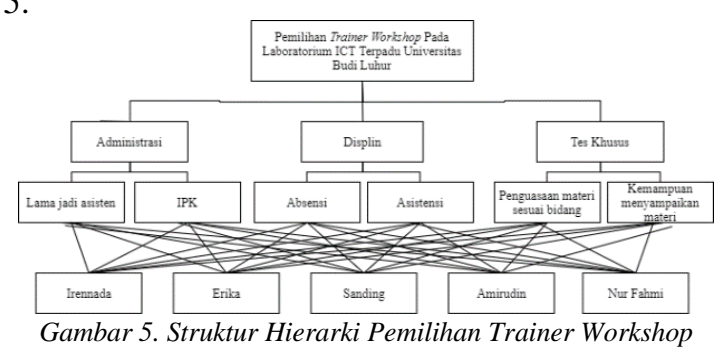

3.5 Perbandingan Kepentingan Antar Kriteria Kuesioner digunakan untuk mendapatkan nilai perbandingan antar kriteria yang akan diisi oleh responden bertujuan untuk mendapatkan besar pembobotan tiap kriteria, adapun nilai perbandingan antar kriteria seperti tersaji pada Tabel 1, dimana tiap kriteria akan dibandingkan dengan kriteria yang lain: 
Tabel 1.Matriks Perbandingan antar Kriteria

\begin{tabular}{|c|c|c|c|}
\hline KRITERIA & Administrasi & Disiplin & $\begin{array}{c}\text { Tes } \\
\text { Khusus }\end{array}$ \\
\hline Administrasi & 1 & $1 / 3$ & $1 / 7$ \\
\hline Disiplin & 3 & 1 & $1 / 5$ \\
\hline Tes Khusus & 7 & 5 & 1 \\
\hline
\end{tabular}

Rumus yang digunakan untuk mendapatkan Consistency Index adalah sebagai berikut [4]:

$\mathrm{CI}=\frac{(z-n)}{n-1} n:$ banyaknya kriteria

$$
\begin{aligned}
& C I=\frac{(3,0654-3)}{3-1} \\
& C I=0,0327
\end{aligned}
$$

Untuk menghitung CI maka dibutuhkan nilai RI yang diperoleh dari tabel Oarkridge.

$C R=\frac{C I}{C R}$

untuk $\mathrm{n}=3$, nilai $\mathrm{RI}$ adalah 5,8

$$
C R=\frac{0,0327}{5,8}
$$

$C R=0,0056$

Perbandingan dianggap konsisten apabila nilai CR tidak melebihi 0,10 sehingga hasil penilaian perbandingan kriteria penentuan trainer workshop pada Laboratorium ICT Terpadu Universitas Budi Luhur Sudah Konsisten dan tidak memerlukan revisi penilaian.

Berdasarkan perbandingan kriteria diatas maka diolah dengan menggunakan metode AHP sehingga didapatkan nilai akhir masing-masing kriteria yang disebut dengan eigenvector, nilai kemudian dikalikan dengan 100 untuk mendapatkan bobot dalam bentuk persentasi. Bobot masing-masing kriteria yang diperoleh dari penerapan metode AHP seperti pada Tabel 2.

Tabel 2. Persentase Bobot Kriteria

\begin{tabular}{|c|c|}
\hline Nama Kriteria & Bobot \\
\hline Administrasi & $7,90 \%$ \\
\hline Disiplin & $18,60 \%$ \\
\hline Tes Khusus & $73,50 \%$ \\
\hline
\end{tabular}

\subsection{Model Keputusan dengan Metode Profile Matching}

Perhitungan menggunakan metode profile matching membutuhan kriteria-kriteria beserta nilai pembobotan dari kriteria-kriteria tersebut. Sehingga akan menghasilkan keluaran dalam bentuk urutan alternatif dari yang paling tinggi sampai dengan alternatif paling rendah. Dalam penelitian ini, setiap kriteria mempunyai subkriteria dan nilai target. Untuk kategori ada 2 (dua) sub yaitu core factor dan secondary factor. Besar bobot untuk core factor adalah $60 \%$, sedangkan besar bobot secondary factor adalah $40 \%$, nilai bobot ini digunakan untuk menghitung nilai dari masing masing kriteria. Berikut merupakan subkriteria beserta nilai target serta penentuan kriteria core factor dan secondary factor dari masing-masing aspek kriteria [5] seperti yang terlihat pada Tabel 3 .
Tabel 3. Nilai Target Subkriteria

\begin{tabular}{|c|l|c|c|}
\hline Kriteria & \multicolumn{1}{|c|}{ Sublcriteria } & $\begin{array}{c}\text { Nilai } \\
\text { Target }\end{array}$ & Status \\
\hline \multirow{2}{*}{ Administrasi } & Lama jadi asisten & 2 & CF \\
\cline { 2 - 4 } & PK & 3 & SF \\
\hline \multirow{2}{*}{ Disiplin } & Absensi & 5 & CF \\
\cline { 2 - 4 } & Asistensi & 4 & SF \\
\hline \multirow{3}{*}{ Tes Khusus } & $\begin{array}{l}\text { Penguasaan materi } \\
\text { Sesuai bidang }\end{array}$ & 5 & CF \\
\cline { 2 - 4 } & $\begin{array}{c}\text { Kemampuan } \\
\text { memvampaikanmateri }\end{array}$ & 4 & SF \\
\hline
\end{tabular}

Studi kasus diambil dari lima asisten sebagai sampel penerapan metode Profile Matching pada pemilihan trainer workshop untuk materi web design yang memiliki data seperti Tabel 4. Nilai A1 s/d A5 sebelum profil adalah nilai masing-masing kandidat sedangkan Nilai Profil adalah nilai target yang akan dicari :

Tabel 4. Tabel Perhitungan Nilai Gap

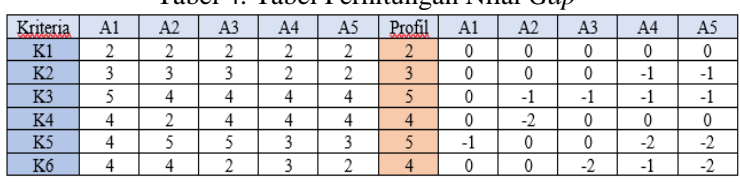

Nilai A1 s/d A5 setelah profil adalah nilai gap diperoleh dari nilai masing-masing kandidat dikurangi dengan nilai profil. Setelah diperoleh nilai gap, kemudian dikonversi menjadi nilai bobot. Berikut ini tabel bobot yang dimiliki tiap kandidat seperti pada Tabel 5.

Tabel 5. Perhitungan Nilai Bobot

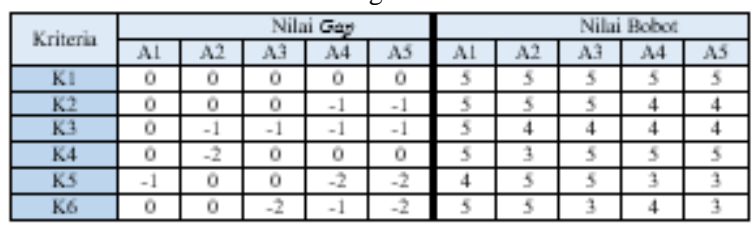

Selanjutnya perhitungan nilai Core Factor dan Secondary Factor. Yang termasuk Core Factor (Faktor Utama) adalah lama jadi asisten, absensi, dan penguasaan materi sesuai bidang. Sedangkan Secondary Factor (Faktor Kedua) adalah IPK, asistensi, dan kemampuan menyampaikan materi, seperti pada Tabel 6 dan hasil perhitungan CF dan SF terlihat pada Tabel 7

Tabel 6. Perhitungan Core Factor dan Secondary Factor

\begin{tabular}{|c|l|l|l|}
\hline Asisten & \multicolumn{1}{|c|}{ Kriteria } & Core Factor & Secondary Factor \\
\hline \multirow{4}{*}{ A1 } & Administrasi & NCF $=\frac{5}{1}=5$ & NSF $=\frac{5}{1}=5$ \\
\cline { 2 - 4 } & Disiplin & NCF $=\frac{5}{1}=5$ & NSF $=\frac{5}{1}=5$ \\
\cline { 2 - 4 } & Tes Khusus & NCF $=\frac{4}{1}=4$ & NSF $=\frac{5}{1}=5$ \\
\hline \multirow{4}{*}{ A2 } & Administrasi & NCF $=\frac{5}{1}=5$ & NSF $=\frac{5}{1}=5$ \\
\cline { 2 - 4 } & Disiplin & NCF $=\frac{4}{1}=4$ & NSF $=\frac{3}{1}=3$ \\
\cline { 2 - 4 } & Tes Khusus & NCF $=\frac{5}{1}=5$ & NSF $=\frac{5}{1}=5$ \\
\hline \multirow{5}{*}{ A3 } & Administrasi & NCF $=\frac{5}{1}=5$ & NSF $=\frac{1}{1}=5$ \\
\cline { 2 - 4 } & Disiplin & NCF $=\frac{4}{1}=4$ & NSF $=\frac{5}{1}=5$ \\
\cline { 2 - 4 } & Tes Khusus & NCF $=\frac{5}{1}=5$ & NSF $=\frac{3}{1}=3$ \\
\hline \multirow{5}{*}{ A4 } & Administrasi & NCF $=\frac{5}{1}=5$ & NSF $=\frac{4}{1}=4$ \\
\cline { 2 - 4 } & Disiplin & NCF $=\frac{4}{1}=4$ & NSF $=\frac{5}{1}=5$ \\
\cline { 2 - 4 } & Tes Khusus & NCF $=\frac{3}{1}=3$ & NSF $=\frac{4}{1}=4$ \\
\hline \multirow{5}{*}{ A5 } & Administrasi & NCF $=\frac{5}{1}=5$ & NSF $=\frac{4}{1}=4$ \\
\cline { 2 - 4 } & Disiplin & NCF $=\frac{4}{1}=4$ & NSF $=\frac{5}{1}=5$ \\
\cline { 2 - 4 } & Tes Khusus & NCF $=\frac{3}{1}=3$ & NSF $=\frac{3}{1}=3$ \\
\hline
\end{tabular}


Tabel 7. Perhitungan Total Nilai

\begin{tabular}{|c|l|l|}
\hline Asisten & \multicolumn{1}{|c|}{ Kriteria } & \multicolumn{1}{c|}{ Perhitungan } \\
\hline \multirow{3}{*}{ A1 } & Administrasi & $\mathrm{Ni}=(60 \% \times 5)+(40 \% \times 5)=5$ \\
\cline { 2 - 3 } & Disiplin & $\mathrm{Ni}=(60 \% \times 5)+(40 \% \times 5)=5$ \\
\cline { 2 - 3 } & Tes Khusus & $\mathrm{Ni}=(60 \% \times 4)+(40 \% \times 5)=4,4$ \\
\hline \multirow{3}{*}{ A2 } & Administrasi & $\mathrm{Ni}=(60 \% \times 5)+(40 \% \times 5)=5$ \\
\cline { 2 - 3 } & Disiplin & $\mathrm{Ni}=(60 \% \times 4)+(40 \% \times 3)=3,6$ \\
\cline { 2 - 3 } & Tes Khusus & $\mathrm{Ni}=(60 \% \times 5)+(40 \% \times 5)=5$ \\
\hline \multirow{3}{*}{ A3 } & Adm inistrasi & $\mathrm{Ni}=(60 \% \times 5)+(40 \% \times 5)=5$ \\
\cline { 2 - 3 } & Disiplin & $\mathrm{Ni}=(60 \% \times 4)+(40 \% \times 5)=4,4$ \\
\cline { 2 - 3 } & Tes Khusus & $\mathrm{Ni}=(60 \% \times 5)+(40 \% \times 3)=4,2$ \\
\hline \multirow{3}{*}{4} & Administrasi & $\mathrm{Ni}=(60 \% \times 5)+(40 \% \times 4)=4,6$ \\
\cline { 2 - 3 } & Disiplin & $\mathrm{Ni}=(60 \% \times 4)+(40 \% \times 5)=4,4$ \\
\cline { 2 - 3 } & Tes Khusus & $\mathrm{Ni}=(60 \% \times 3)+(40 \% \times 4)=3,4$ \\
\hline \multirow{3}{*}{ A5 } & Administrasi & $\mathrm{Ni}=(60 \% \times 5)+(40 \% \times 4)=4,6$ \\
\cline { 2 - 3 } & Disiplin & $\mathrm{Ni}=(60 \% \times 4)+(40 \% \times 5)=4,4$ \\
\cline { 2 - 3 } & Tes Khusus & $\mathrm{Ni}=(60 \% \times 3)+(40 \% \times 3)=3$ \\
\hline
\end{tabular}

Selanjutnya adalah perhitungan nilai akhir dari setiap kandidat seperti pada Tabel 8.

Tabel 8. Perhitungan Penentuan Ranking

\begin{tabular}{|c|c|l|}
\hline Nama Asisten & \multicolumn{1}{|c|}{ Perhitungan Ranking } \\
\hline \multirow{3}{*}{ A1 } & $=$ & $(7,90 \% \times 5)+(18,60 \% \times 5)+(73,50 \% \times 4,4)$ \\
\cline { 2 - 3 } & $=$ & $0,3950+0,9300+3,2340$ \\
\cline { 2 - 3 } & $=$ & $\mathbf{4 , 5 5 9 0}$ \\
\hline \multirow{3}{*}{ A3 } & $=$ & $(7,90 \% \times 5)+(18,60 \% \times 3,6)+(73,50 \% \times 5)$ \\
\cline { 2 - 3 } & $=$ & $0,3950+0,6690+3,6750$ \\
\cline { 2 - 3 } & $=$ & $\mathbf{4 , 7 3 9 6}$ \\
\hline \multirow{3}{*}{ A4 } & $=$ & $(7,90 \% \times 5)+(18,60 \% \times 4,4)+(73,50 \% \times 4,2)$ \\
\cline { 2 - 3 } & $=$ & $0,3950+0,8184+3,0870$ \\
\cline { 2 - 3 } & $=$ & $\mathbf{4 , 3 0 0 4}$ \\
\hline \multirow{3}{*}{ A5 } & $=$ & $(7,90 \% \times 4,6)+(18,60 \% \times 4,4)+(73,50 \% \times 3,4)$ \\
\cline { 2 - 3 } & $=$ & $0,3634+0,8184+2,4990$ \\
\cline { 2 - 3 } & $=$ & $\mathbf{3 , 6 8 0 8}$ \\
\hline & $=$ & $(7,90 \% \times 4,6)+(18,60 \% \times 4,4)+(73,50 \% \times 3)$ \\
\cline { 2 - 3 } & $=$ & $0,3634+0,8184+2,2050$ \\
\cline { 2 - 3 } & $=$ & $\mathbf{3 , 3 8 6 8}$ \\
\hline & &
\end{tabular}

Berdasarkan nilai akhir tiap kandidat diurutkan dari nilai terbesar ke terkecil untuk mendapatkan rangking seperti pada Tabel 9. Sehingga didapatkan hasil rangking tertinggi adalah kandidat A2 dengan nilai 4,7396 yang merupakan kandidat yang paling sesuai untuk dipilih jadi trainer materi web design

Tabel 9. Hasil Perankingan Asisten pada Materi Web Design

\begin{tabular}{|c|c|c|c|c|}
\hline Nam a Asisten & $\mathrm{Ni}$ & $\mathrm{Ns}$ & $\mathrm{Np}$ & H a sil Akhir \\
\hline A2 & $\mathbf{5}$ & $\mathbf{3 , 6}$ & $\mathbf{5}$ & $\mathbf{4 , 7 3 9 6}$ \\
\hline $\mathrm{A} 1$ & 5 & 5 & 4,4 & 4,5590 \\
\hline $\mathrm{A} 3$ & 5 & 4,4 & 4,2 & 4,3004 \\
\hline $\mathrm{A} 4$ & 4,6 & 4,4 & 3,4 & 3,6808 \\
\hline $\mathrm{A} 5$ & 4,6 & 4,4 & 3 & 3,3868 \\
\hline
\end{tabular}

\subsection{Model Data}

\section{a. Entity Relationship Diagram (ERD)}

Diagram ini digunakan untuk menganalisa kebutuhan simpanan data yang akan dibuatkan menjadi sebuah database seperti pada Gambar 6 .

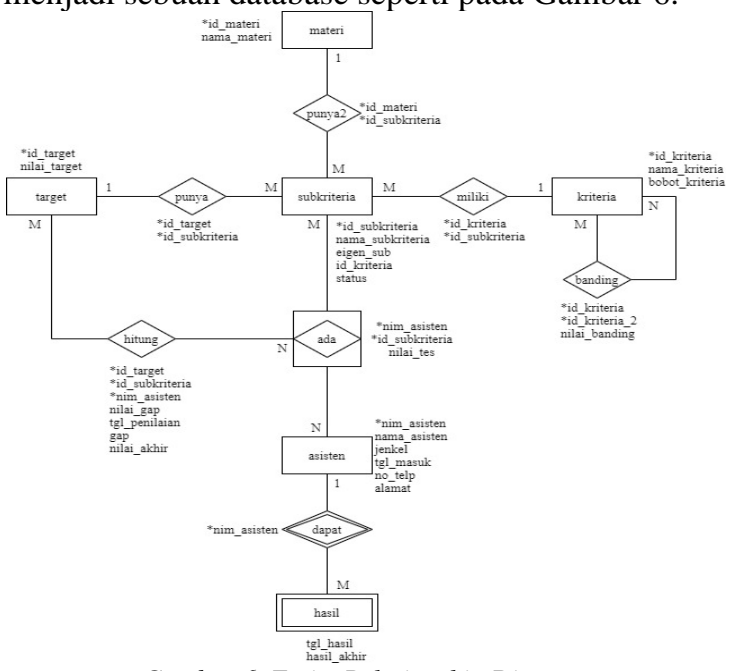

Gambar 6. Entity Relationship Diagram

\section{b. Logical Record Structure (LRS)}

Berdasarkan ERD dikonversi menjadi Logical Record Structure untuk mempermudah dalam menghubungkan antara entitas yang satu dengan entitas yang lainnya, seperti Gambar 7.

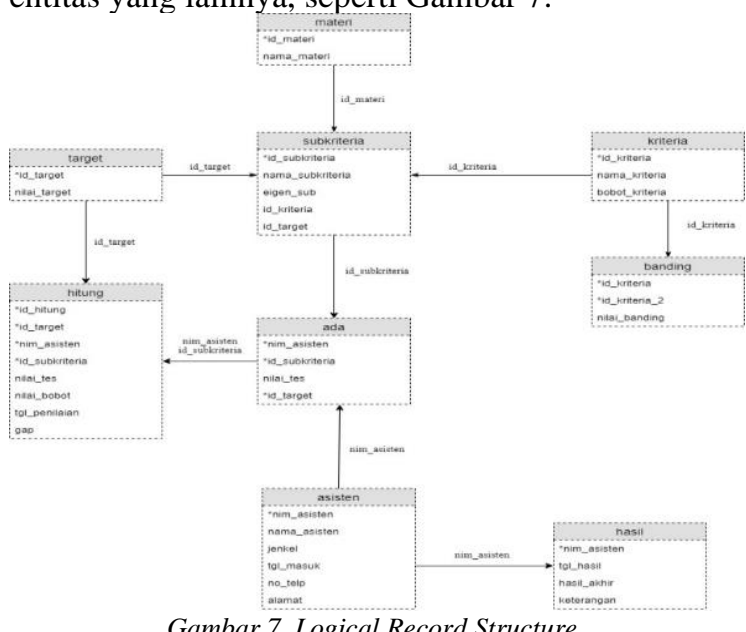

\subsection{Use Case Diagram}

Use case diagram digunakan untuk memodelkan perilaku sistem informasi yang akan dirancang. Use case diagram digunakan untuk menggambarkan proses apa saja yang terdapat dalam sebuah sistem. [8]

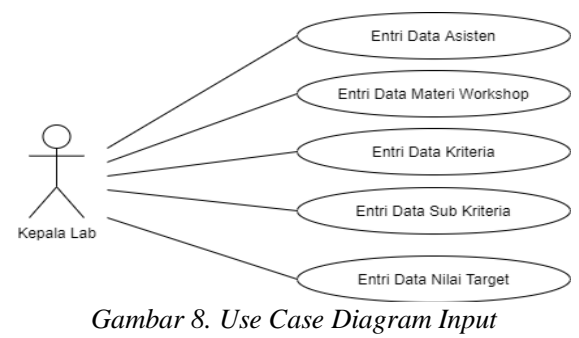

Pada Gambar 8. Terdapat 5 proses yang akan dibuat menjadi 5 modul dalam program, adapun modul tersebut digunakan untuk input data master kedalam sistem.

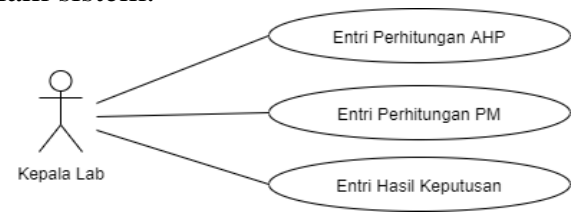

Gambar 9. Use Case Diagram Proses

Pada Gambar 9. Terdapat 3 proses yang akan dibuat kedalam 3 modul dalam program, adapun modul tersebut digunakan untuk proses perhitungan mencari pembobotan kriteria dan perhitungan profile matching dan proses pengambilan keputusan.

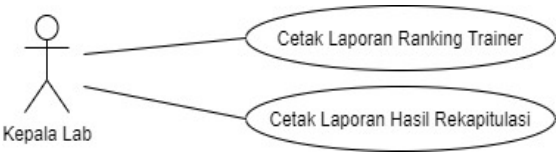

Gambar 10. Use Case Diagram Output

Pada Gambar 10. Terdapat 2 output yang akan dibuat kedalam 2 modul dalam program, adapun 
modul tersebut digunakan mencetak hasil keluaran program.

\subsection{Rancangan Layar}

1. Rancangan Layar Data Nilai Target

Berikut adalah interface dalam program untuk entri data nilai target per kriteria. Seperti pada Gambar 11.

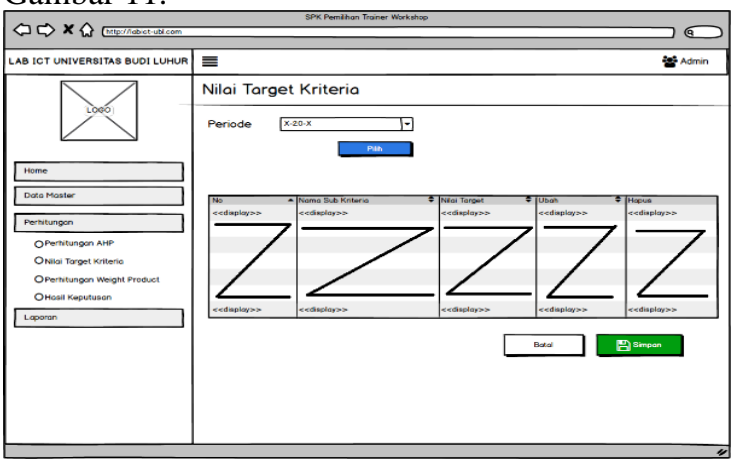

Gambar 11. Rancangan Layar Data Nilai Target

2. Rancangan Layar Perbandingan Kriteria

Berikut adalah interface dalam program untuk matriks perbandingan kriteria, merupakan hasil perhitungan metode AHP. Seperti pada Gambar 12.

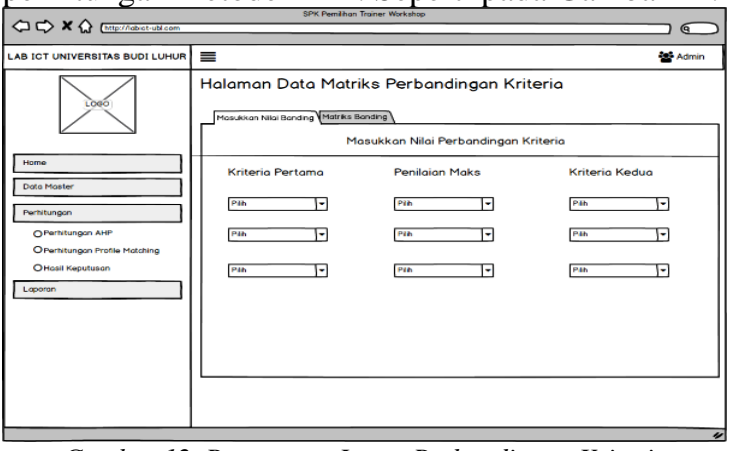

Gambar 12. Rancangan Layar Perbandingan Kriteria

3. Rancangan Layar Perhitungan Profile Matching

Berikut adalah interface dalam program untuk perhitungan profile matching, merupakan modul untuk mencari nilai akhir tiap kandidat. Seperti pada Gambar 13.

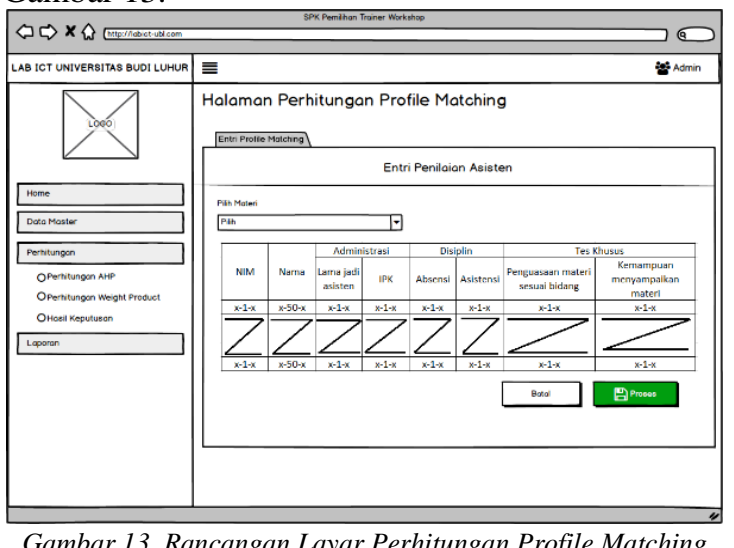

4. Rancangan Layar Entry Hasil Keputusan

Berikut adalah interface dalam program untuk hasil keputusan pemilihan trainer workshop, merupakan modul untuk pengambilan keputusan. Seperti pada Gambar 14.

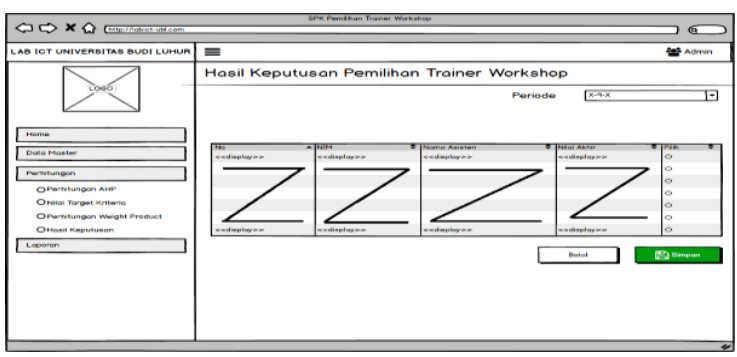

Gambar 14. Rancangan Layar Entry Hasil Keputusan

\subsection{Hasil Penelitian}

Berdasarkan analisa dan pembahasan penelitian dengan menggunakan metode Analytical Hierarchy Process dan Profile Matching maka dihasilkan nilai akhir masing-masing alternatif. Pada contoh kasus pemilihan trainer workshop materi web design, seperti Tabel 10. maka kandidat yang paling sesuai untuk menjadi trainer materi Web desain adalah A2 karena hasil akhir nya merupakan nilai yang tertinggi dibanding kandidat lainnya. Tabel 10. Hasil Penelitian

\begin{tabular}{|c|c|c|c|}
\hline No. & Asisten & Hasil Alkhir & Peringlcat \\
\hline 1 & A.1 & 4,5590 & 2 \\
\hline 2 & A2 & 4,7396 & 1 \\
\hline 3 & A3 & 4,3004 & 3 \\
\hline 4 & A4 & 3,6808 & 4 \\
\hline 5 & A5 & 3,3868 & 5 \\
\hline
\end{tabular}

\section{KESIMPULAN}

Berdasarkan pembahasan dan analisa yang telah dilakukan pada Laboratorium ICT Terpadu Universitas Budi Luhur maka dapat ditarik beberapa kesimpulan, yaitu:

a. Dengan penggunaan sistem penunjang keputusan ini maka proses pemilihan trainer workshop dapat dilakukan dengan tepat karena menggunakan metode Analytical Hierarchy Process (AHP) sebagai penentuan bobot dari kriteria yang digunakan untuk acuan pemilihan trainer workshop per kriteria dan metode Profile Matching sebagai proses perangkingan. Sehingga proses pemilihan trainer workshop lebih bersifat obyektif dalam penilaiannya.

b. Berdasarkan kuesioner persetujuan kriteria, bahwa kriteria yang ditetapkan pada proses pemilihan trainer workshop yaitu Administrasi, Disiplin, dan Tes Khusus serta untuk mendapatkan besar pembobotan masing-masing kriteria menggunakan metode Analytical Hierarchy Process (AHP). Bobot kriteria yang telah didapatkan berdasarkan kuesioner yaitu, Administrasi dengan nilai eigenvector 0,0790, Disiplin dengan nilai eigenvector 0,1860, dan Tes Khusus dengan nilai eigenvector 0,7350. Dan nilai eigenvector tersebut sudah konsisten dengan nilai Consistency Ratio 0,0056.

c. Dengan adanya sistem penunjang keputusan pemilihan trainer workshop diharapkan dapat membantu Kepala Laboratorium dalam melakukan pengolahan data, perhitungan nilai akhir, dan pencetakan laporan hasil keputsan karena semuanya dilakukan di dalam satu sistem, sehingga dapat meminimalkan kesalahan dan 
mempercepat proses penentuan trainer workshop.

Dengan adanya sistem penunjang keputusan ini maka diharapkan dalam proses pemilihan trainer workshop mendapatkan hasil yang sesuai dengan materi yang dikuasai oleh masing-masing asisten sehingga asisten yang terpilih sebagai trainer workshop dapat lebih mendalami materi yang telah dikuasai.

\section{DAFTAR PUSTAKA}

[1] Aji, Purwo Setyo, and Mahdiana, Deni, "Penerapan Metode SAW Pada Sistem Penunjang Keputusan Penilaian Calon Asisten Lab ICT Terpadu Universitas Budi Luhur", Jurnal IDEALIS, vol. 2(4), pp. 154-158, Juli 2018.

[2] Lubis, Dewi Shinta W., and Murlisah, Eka, "Sistem Pendukung Keputusan Pemilihan Trainer Menggunakan Metode ARAS (Additive Ratio Assesment)," in Seminar Nasional Teknologi Komputer \& Sains (SAINTEKS 2019), 2019, pp.448-455.

[3] Heruansyah, Ananda and Juanita, Safitri, "Implementasi Metode AHP dan SAW Pada Aplikasi Sistem Penunjang Keputusan Supplier Terbaik Studi Kasus: CV. Sentra Jamu Indonesia", Jurnal IDEALIS, vol. 2(4), pp. 198-204, Juli 2019

[4] Sensuse, Dana Indra and Sari, Fitria Rahma "Penerapan Metode Analytic Hierarchy Process Process Dalam Sistem Penunjang Keputusan Untuk Pemilihan Asuransi," Jurnal Sistem Informasi, vol. 4(2), pp. 100-109, Oktober 2008.

[5] Liang, Xiaohui, et all, Security and Privacy in Mobile Social Networks. London: Springer New York Heidelberg Dordrecht, 2013.

[6] Nofriansyah, Dicky, \& Defit, Sarjon, Multi Criteria Decision Making (MCDM) pada Sistem Pendukung Keputusan. Yogyakarta: DeePublish, 2017.

[7] Tohari, Hamim, Analisis Serta Perancangan Sistem Informasi Melalui Pendekatan UML. Yogyakarta: Andi Offset, 2014.

[8] A. S. Rosa \& Shalahuddin, M., Rekayasa Perangkat Lunak Terstruktur dan Berorientasi Objek. Bandung: Informatika, 2013. 